Open Access

\title{
The impacts of entrepreneurial orientation on the profitability growth of construction firms in Tanzania
}

\author{
Fred Phanuel Okangi®
}

\author{
Correspondence: \\ fredokangi@yahoo.com; \\ http://www.udbs.udsm.ac \\ Univesity of Dar es Salaam Business \\ School, Office No. C628, UDBS \\ Building Phase III, P.O.BOX 35046, \\ Dar es Salaam, Tanzania
}

\begin{abstract}
Literature considers entrepreneurship as an important catalyst in the process of improving firm performance and growth. This study analyzes the impacts of entrepreneurial orientation (EO) dimensions (i.e., innovativeness, proactiveness, and risk taking) on the profitability growth of local Tanzania's construction firms. A survey to 132 Tanzanian construction firms was undertaken using a questionnaire. With the help of STATA 13.0 Software, data collected was analyzed by using a multiple regression analysis. The findings show that both innovativeness and risk taking dimensions have a significantly positive effect on the growth of profitability for local Tanzania's construction firms, whereas the proactiveness dimension has a negative significant effect. This study contributes to the field of entrepreneurship in developing countries and enhances the knowledge of the impacts of EO dimensions on the profitability growth of firms (in particular construction firms).

Keywords: Entrepreneurship, Entrepreneurial orientation, Construction industry, Tanzania, Developing countries, innovativeness, Risk taking, Proactiveness
\end{abstract}

\section{Introduction}

Firms are turning towards entrepreneurship to promote continual innovation, rapid growth, value creation, competitive advantage as well as improve efficiency and productivity (Ferreira and Azevedo 2008). Entrepreneurship not only stimulates business development, job creation, economic growth, profitability, innovation, and income generation (Brush et al. 2006), but also is a fundamental driver of the growth of an organization (Erken et al. 2008). Entrepreneurship encourages innovation that has a positive effect on the growth of organizations (Hughes and Morgan 2007). Companies need novel ideas to be successful and entrepreneurship can provide themby employing the resources that are available to establish a profitable business (Dean and McMullen 2007; Shane and Venkataraman 2000).

Entrepreneurial activities are playing an important role in achieving firm's goals (Kraus et al. 2012). It significantly contributes to the growth of different organizations (Setiawan et al. 2012; Antoncic and Zorn 2004). Further, entrepreneurship increases innovation, knowledge, competition, and diversity in different sectors and organizations (Santarelli and Vivarelli 2007). Entrepreneurship is helpful in developing strategies appropriate for improving the growth of firms (Yoon 2012; Bhardwarj

(c) The Author(s). 2019 Open Access This article is distributed under the terms of the Creative Commons Attribution 4.0 International License (http://creativecommons.org/licenses/by/4.0/), which permits unrestricted use, distribution, and reproduction in any medium, provided you give appropriate credit to the original author(s) and the source, provide a link to the Creative Commons license, and indicate if changes were made. 
et al. 2011; Cader and Norman 2006; Zahra 1996). Furthermore, the mainstream literature suggests that "entrepreneurial orientation (EO) leads to higher growth among those firms exercising it" (Sarker and Palit 2015). Zulkifli and Rosli (2013) also reports that EO variable has significant effect on the business growth of Malay entrepreneurs.

Generally, most research have established that "EO variable is significantly related to the growth of firms" (Neneh and Van Zyl 2017; Gupta and Batra 2016; Kim et al. 2015). Due to its significance, some countries have developed policies that promote EO (Minniti and Levesque 2008; Brush et al. 2006). Tanzania being one of those countries implementing EO has developed policies for promoting competitiveness and growth of firms (see Sutton and Olomi 2012). According to Sutton and Olomi however, many Tanzania's firms in different sectors including firms in the construction industry have not been unsuccessful in incorporating entrepreneurship in their operations.

Based on the established effects of entrepreneurial orientation (EO) on the performance and growth of firms, this study investigates the impact of different dimensions of EO on the growth of local Tanzanian construction firms. I focused on Tanzania's construction industry because a few studies on EO conducted in Tanzania were focusing on firms operating in sectors other than construction industry. For example, Mahemba and Bruijn (2003) exhibited a positive relationship between innovativeness and firm growth of firms in Tanzania's manufacturing sector. Another study by Philemon and Kessy (2009) on top management characteristics and firm performance in Tanzania focusing on financial, manufacturing, and tourism institutions also indicated a positive relationship between EO dimensions (innovativeness, proactiveness, and risk taking) and firm performance. Thus, studies on effects of EO looking at the specific contexts of Sub-Saharan countries in particular Tanzania are still lacking. Another motive for this study is because Tanzania was not affected by civil wars or other structural breaks over recent decades and thus it would adequately represent entrepreneurship of several Sub-Saharan countries. With a Gross Domestic Product (GDP) of approximately 650 US-\$ per capita (app. 1700 US-\$ in 2013), it belongs to the top $10 \%$ of the poorest countries in the world. Finally, I decided to analyze the construction industry because it makes a substantial contribution to Tanzania's economy - accounting for more than $5 \%$ of its annual GDP (National Bureau of Statistics 2013). Therefore, investigating the impacts of individual dimensions of EO on the profitability growth of local Tanzania's construction firms is of great importance.

\section{Entrepreneurship development in Tanzania}

During colonial days in Tanzania, "indigenous productive activities were hindered by colonial regulations and competition from imports. Throughout the colonial period, Tanzania's industries were designed to provide raw materials for use in industries in Europe" (Olomi 2009). As provided by Rweyemamu (1979), "the deliberate policy to limit participation of indigenous Tanzanians in business activities restricted business opportunities to small enterprises such as tiny shops" (As a result, the development of entrepreneurial values in terms of building competence and confidence in pursuing opportunities, creativity, risk taking ability, etc. (Abrams 2004) among the individual Tanzanians were negatively affected (Olomi 2009).

After the independence of the then Tanganyika (now Tanzania) in 1961, a 5 year development plan (1961-1966) was introduced to attract private and foreign investors in 
the country. However, the plan was unsuccessful as it failed to attract private investors in the economy. As a result, in 1967, the Tanzania's government adopted socialist policy through Arusha declaration that aimed at "nationalization of the existing enterprises and establishing new organizations dealing with businesses in the country" (Rugumamu 1997). The implementation of the socialist policy in the country led to discourage entrepreneurship process at individual level in favor of government owned firms (Temu 1997; Maliyamkono and Bagachwa 1990). As a result, "the development of entrepreneurial values such as the willingness to take initiatives and risks, creativity, the need for achievement and related competencies dwindled among the majority of Tanzanians" (Olomi 2009).

The entrepreneurship development in Tanzania "emerged as a result of the economic crisis that began in the mid-1970s and intensified in the early 1980s" (Olomi 2009). According to Ndunguru (2006), "the crisis forced the government to implement a radical transformation program under the support of the World Bank (WB) and the International Monetary Fund (IMF) in 1986. The Economic Restructuring Programme (ERP) was motivated by the need to fill the entrepreneurial space created by the divestment of state-owned enterprises and the liberalized economy in 1986". In implementing the ERP, the private sector was given a priority in building the economy and the government was responsible to facilitate and support the individuals as private firms by creating a favorable environment for business growth (Olomi 2009).

Due to the combinations of these factors, the entrepreneurial values have been demonstrated by local Tanzania's construction firms in different ways. For example, innovativeness has been demonstrated through the use of local construction materials and has reduced construction costs. Other innovativeness initiatives applied by local Tanzania construction firms include promoting collaboration among contractors, significant changes in organizational structures, use of effective management practices, improvement of communication and sharing of important information among the company's employees, significant changes in products, improvement of production processes, and development of new products. The developments have been made possible through knowledge acquisition from different sources such as in-house knowledge dissemination, education, trainings, etc.

Currently, Tanzania's construction firms are practicing proactiveness in different ways like the use of capital rotation. Capital rotation refers to a use of funds from the already paid projects to facilitate the ongoing projects. Other examples of proactive initiatives by local Tanzania's construction firms include employing expertise and experienced consultants to avoid delays and substandard outputs, building good relationship with financial institutions, and forming joint ventures among themselves and with foreign contractors in execution of construction projects. In general, the improved entrepreneurial values among local Tanzania's construction firms are a result of the liberalization of the Tanzania's economy (Sutton and Olomi 2012). Therefore, the present study set to investigate EO dimensions relates to the growth of local Tanzania's construction firms. The study contributes to the body of existing knowledge on entrepreneurship by providing context-specific evidence of factors that can potentially improve entrepreneurship and economic growth in developing countries, particularly in Tanzania. 


\section{Theories and hypotheses \\ Entrepreneurship}

Entrepreneurship refers to a process and set of business activities pursuing new opportunities (Hayton and Kelley 2006). It helps firms to exploit market opportunities through innovation (Schumpeter 1965) in response to customer needs identified in the firm's business environment (Onuha 2007). Entrepreneurship motivates people to mobilize important resources for the survival of their organizations (Krueger 2005) and drives firms to pursue a range of growth strategies (Knight 1997). In this study, the definition of entrepreneurship is considered by reflecting on the keywords of entrepreneurship provided by Stevenson and Jarillo-Mossi (1986, p.10). Jarillo-Mossi defined entrepreneurship as " $a$ process of creating value by bringing together a unique package of resources to exploit an opportunity".

Entrepreneurship is an important driver of economic growth and corporate success (Kraus et al. 2012) that enables firms to achieve economic growth and competitiveness (Wennekers 2004). Success of firms require "competitive strategies" (Zahra 1993), different from those of the firms already in the market (Gambatese and Hallowell 2010). Entrepreneurial behavior is influenced by risk taking propensity, educational influence, work experience, the locus of control,, family influence, the need for independence, recognition, the need for achievement, and the need to be one's own boss (Vij and Bedi 2012). However, in the 1980s and 1990s, researchers moved from focusing on the determinants of entrepreneurship to identifying dimensions of entrepreneurial orientation (EO) (Vij and Bedi 2012; Lumpkin and Dess 1996).

\section{Entrepreneurial orientation}

Entrepreneurial Orientation (EO) refers to "a process, practice, and decision making style of organizations that act entrepreneurially" (Ketchen and Short 2012; Lumpkin and Dess 1996). EO is considered to be a key concept for exploiting opportunities that competitors cannot pursue (Ketchen and Short 2012). Many scholars agree that EO is "a combination of innovativeness, proactiveness, and risk taking” (Ketchen and Short 2012; Schillo 2011; Kreiser et al. 2002; Lumpkin and Dess 2001; Zahra and Garvis 2000; Lumpkin and Dess 1996; Naman and Slevin 1993; Miles et al. 1993; Miles and Arnold 1991; Covin and Slevin 1991; Covin and Slevin 1989):

- Innovativeness refers to the tendency of pursuing creativity and experimentation (Ketchen and Short 2012). It reflects on engaging in "new ideas and creative processes that lead to new products, services, and processes" (Hult et al. 2004; Kreiser et al. 2002; Lumpkin and Dess 1996). Innovativeness is an important aspect of EO because "it helps firms to pursue new opportunities" (Ketchen and Short 2012).

- Proactiveness refers to "a process that aims at anticipating and acting on future opportunities in terms of products, technologies and markets" (Schillo 2011) rather than "reacting to events after they unfold" (Ketchen and Short 2012). Proactiveness aims at introducing new products ahead of competitors, "strategically eliminating operations that are in the declining stages of the business life cycle" (Antoncic and Zorn 2004). Proactiveness shows "how firms relate to market opportunities by 
seizing the initiative in the market place" (Ying-hong 2007). Proactive firms have "the desire to be pioneers" (Reijonen et al. 2014) by acting in advance and capitalizing on emerging opportunities (Ketchen and Short 2012).

- Risk taking is one of the internal organizational factors necessary to support entrepreneurship within organizations (Hornsby et al. 2002). It refers to a firm's tendency to engage and the willingness to commit significant resources to opportunities with uncertain outcomes (Schillo 2011; Lumpkin and Dess 1996). Risk taking ability helps firms to engage in bold rather than cautious actions (Ketchen and Short 2012). However, "entrepreneurship does not entail reckless decision-making, but reasonable awareness of the risks and being able to calculate and manage these risks" (Naldi et al. 2007).

\section{Entrepreneurial orientation and the growth of firms}

Firm growth refers to an increase in the size and the output of a firm and is very closely related to its survival (Davidsson et al. 2005). Entrepreneurial orientation (EO) is one of the factors that determines the growth of firms (Pratono et al. 2013; Mahmood and Hanafi 2013; Yoon 2012; Setiawan et al. 2012; Kraus et al. 2012; Bhardwarj et al. 2011; Soriano 2010; Rauch et al. 2009; Ferreira and Azevedo 2008; Krauss et al. 2005; Krueger 2005; Knight 1997; Zahra 1996; Lumpkin and Dess 1996; Covin and Slevin 1989; Stevenson and Jarillo-Mossi 1986; Hansen and Wernerfelt 1989). Empirical findings from other studies (Mahmood and Hanafi 2013; Zhang and Zhang 2012; Li et al. 2009; Ferreira and Azevedo 2008; Krueger 2005; Zahra 1996; Lumpkin and Dess 1996; Covin and Slevin 1989) also provide evidence that "EO has a significant and positive relationship with firm performance andgrowth". Moreover, a study by Zain and Hassan (2007) among the firms in Malaysia and Alarape (2013) on the performance of Nigerian firms suggested that "EO has a positive impact on the growth of firms".

Empirical findings further indicate a lack of consistency on the effects of $\mathrm{EO}$ and its dimensions on the growth of firms/businesses (Rauch et al. 2009; Wang 2008; Naldi et al. 2007; Hughes and Morgan 2007; Rauch et al. 2009; Lumpkin and Dess 1996). According to Hughes and Morgan (2007) and Rauch et al. (2009), the effects of individual dimensions of EO were found to vary independently with firm's growth. In those studies, proactiveness and innovativeness dimensions were found to positively related to the firm's performance and growth while risk taking dimension was negatively associated with the performance and growth of firms. Lumpkin and Dess (1996) also indicated that the effects of EO dimensions on growth of organizations vary. Another contradicting finding on the impacts of EO on growth of firms is from a study by Naldi et al. (2007) where risk taking variable demonstrated a negative relationship with growth of firms. Wang (2008) exhibited that relationship between EO and firm performance is mediated by learning orientation whereby flexibility and application of required skills in doing things are encouraged within the firm. In summary, literatures show that not all of the dimensions of EO directly or positively affect business growth when the industry's contextual factors are considered (Rauch et al. 2009; Lumpkin and Dess 1996).

Despite the contradiction of the results on the effects of EO and its dimensions on the growth of firms, this study however, was built on a basis that there is a positive relationship between the individual dimensions of EO and the growth of firms. This is 
because of the significant impacts of EO and its dimensions in influencing growth of firms (e.g., Kraus et al. 2012; Bhardwarj et al. 2011; Rauch et al. 2009; Ferreira and Azevedo 2008; Krueger 2005; Knight 1997; Zahra 1996; Lumpkin and Dess 1996; Covin and Slevin 1989). I then adopted and modified the conceptual framework from Swierczek and $\mathrm{Ha}$ (2003a, 2003b) to hypothesize the relationship between the dimensions of EO and firm growth. The model (see also Brettel et al. 2015) is made of three components. The first component presents the dimensions of $\mathrm{EO}$, while the second component of the model presents the control variables employed in this study. It is important to consider the control variables in the analysis because they reduce the effect of dependent variable (i.e., profitability growth in this case) on confounding variables. The third component of the model presents profitability growth as a result of EO practices in the firm. Figure presents the model for this study (Fig. 1).

Related to this model, I formulated three hypotheses and tested them by employing a survey study to 132 construction firms in Tanzania. Despite the inconsistent findings of the effects of EO dimensions on growth of firms; I formulated the hypotheses based on the previous findings that EO dimensions have a positive and significant impact on the growth of firms; I thus hypothesized that all three dimensions of EO to be positively related to the profitability growth of local Tanzania's construction firms.

\section{Innovativeness and profitability growth}

Innovativeness can help firms to pursue "new opportunities" (Wang and Altinay 2012; Wiklund and Shepherd 2005) and contributes significantly to the success of firms (Lim et al. 2010; Gambatese and Hallowell 2010; Slaughter 2010). Innovativeness has the ability to help firms to improve their positions in the market and improve the quality of their products and services (Setiawan et al. 2012; Lim et al. 2010). Innovations can also "improve cost efficiency and increase productivity in the company" (Lim et al. 2010) as well as "stronger growth than those that do not put more effort into innovation" (Ketchen and Short 2012). Types of innovation in business include; product innovation, market innovation, market development, and process innovation (North and Smallbone 2000). As for construction industry in particular, Bossink (2004) identified factors such as; "environmental pressure, technological capability, knowledge exchange, and boundary spanning as

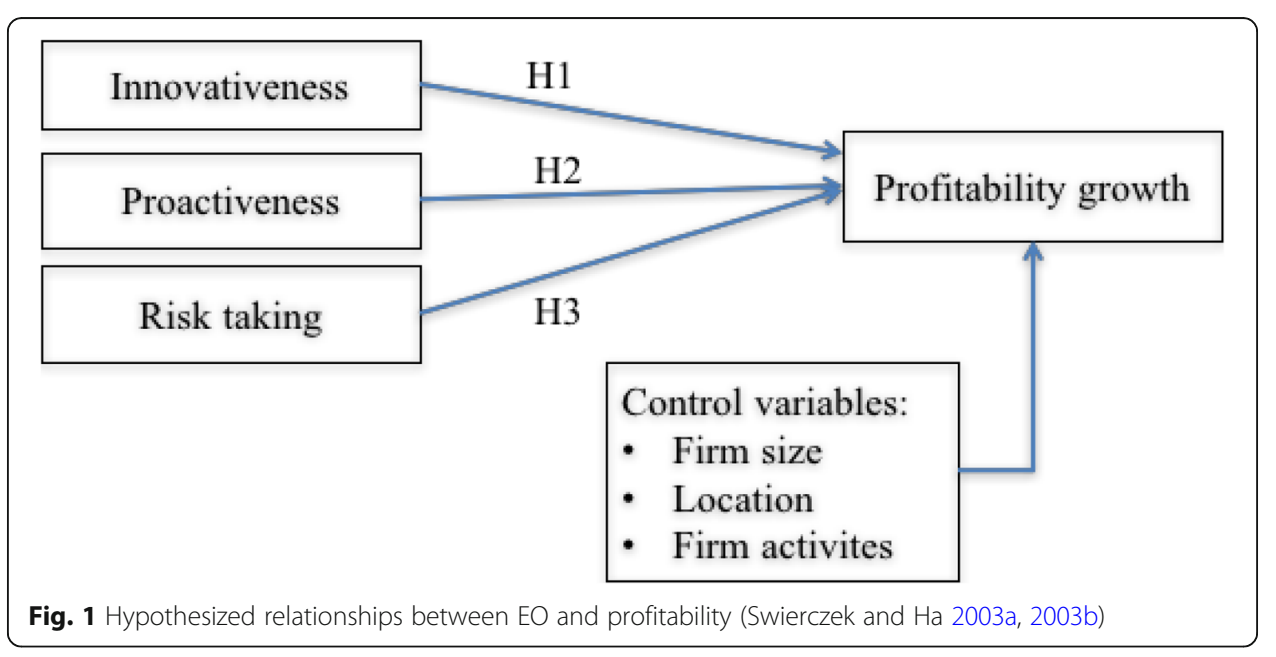


drivers of innovation". Environmental pressure driver results from the need of regulations where the construction firm operates while technological capability driver refers to programmes promoting innovation of products and process in the organization. Knowledge exchange driver involves sharing information that can facilitate innovation among employees, while boundary spanning driver is an initiative involving key stakeholders in the generating and implementing innovation idea.

In general, innovativeness have influence on growth of firms (Setiawan et al. 2012; Ketchen and Short 2012; Lim et al. 2010; Gambatese and Hallowell 2010; Slaughter 2010). As demonstrated by Wang and Yen (2012), "innovativeness is positively related to firm growth". A study by Casillas and Moreno (2010) and Awang et al. (2010) also indicate that innovativeness have a significant and positive association with firm performance. Firms with sound innovation were found to perform better than those with less innovation (Wiklund and Shepherd 2005; Rauch et al. 2009). More studies on the effects of EO on performance and growth of firms confirm a significant and positive effect of innovativeness on firm growth (Kraus 2013; Kraus et al. 2012; Su et al. 2011; Lee and Lim 2009). Given the significant impacts of the innovativeness on firm's growth in sectors other than construction industry (e.g. Philemon and Kessy 2009; Mahemba and Bruijn 2003; Kreiser et al. 2002), I hypothesize the following:

H1: Innovativeness is positively related to the profitability growth of local Tanzania's construction firms.

\section{Proactiveness and profitability growth}

Firms that are proactive in pursuing opportunities can achieve more profit than those that are not proactive in the market (Lumpkin and Dess 1996). This is because "the more proactive the firm is in capturing new business opportunities, the greater the growth rates of the firm" (Casillas and Moreno 2010). The firm's ability in forecasting the future market needs provide that firm with an avenue of undergoing required changes that can help it in taking advantage over rivals in the market (Morgan and Strong 2003). Proactiveness "equips firms with the ability to respond positively to market opportunities" (Kreiser et al. 2002; Lumpkin and Dess 1996). Consequently, proactiveness can improve growth of a firm developing new business models (Zahra 1996). The positive effects of proactivenes on growth of firms was also exhibited by Fairoz et al. (2010) when they measured the link that exists between the dimensions of EO and firm performance in Sri Lanka Likewise, Kasumawardhani et al. (2009) also found a positive and significant impact of proactiveness on the performance and growth of firms I Sri Lanka. Another study by Farja et al. (2016) in Israel indicated that the higher the level of proactiveness in a company, the higher the level of growth was realized in such companies. In summary, as a result of the empirical findings provided, I derive the following hypothesis:

H2: Proactiveness is positively related to the profitability growth of local Tanzania's construction firms. 


\section{Risk taking and profitability growth}

Empirical findings show how the intensity of risk taken by firms is associated with outcomes (Peng 2015; Wang and Yen 2012; Gibb and Haar 2010; Casillas and Moreno 2010). For example, Gibb and Haar (2010) demonstrated that firms in New Zealand with a higher risk profile were able to experience higher financial rewards. Wang and Yen (2012) is another study which justifies a positive association that exists between risk taking variable and performance among Taiwanese companies. A positive relationship between risk taking variable and firm growth was also demonstrated by Casillas and Moreno (2010). Peng (2015) also found existence of a significant effect of risk taking variable on firm's earnings as well as growth. According to Ambad and Wahab (2013) firms that are able to commit significant resources to projects with high risks are the ones with advantage of realizing higher outputs in terms of incomes generated. Generally, studies across the World confirm the existence of a positive and significant effect of the risk taking on firm performance as well as firm growth (Zhang and Zhang 2012; Kraus et al. 2012; Su et al. 2011; Kasumawardhani et al. 2009; Lee and Lim 2009; Li et al. 2009; Wiklund and Shepherd 2005; Miller 1983). Therefore, I tested the following hypothesis:

H3: Risk taking is positively related to the profitability growth of local Tanzania's construction firms.

\section{Control variables}

In this study, the number of employees, location, and firm activities variables were controlled. "These control variables are commonly used in EO studies" (Kraus et al. 2012; Wiklund and Shepherd 2005; Zahra and Garvis 2000). Firms with different numbers of employees, location, and industry (firm activities) may exhibit different organizational characteristics, which can affect their profitability growth.

- The employees' number is "one of the common control factors in studies on firm growth” (Weinzimmer et al. 1998). During the survey, respondents were asked to indicate the number of employees that the company had in the year 2012, which was the final year of the data collected for this study.

- In this study, the five different types of contractors, namely: building, civil, mechanical, electrical, and specialist contractors were differentiated. However, this study only focuses on two categories of contractors, namely, building and civil contractors due to their big number of registration but with poor growth trends (National Bureau of Statistics 2013). For example, registered contractors for building and civil works were 5418 (which is 80\%) out of all registered 6762 contractors in Tanzania by the end of year 2012. The remaining 20\% of the registered companies belong to electrical, mechanical, and specialist contractors. It is important to consider the number of contractors registered until 2012 because the number of contractors does change at some points with some new companies being registered while others which are not complying with the CRB's requirements are deleted from the list of contractors. Consequently, firms' activities were determined by asking respondents to "indicate the firm's main line of business" 
(Varukolu and Park-Poaps 2009), which is building works or civil works (or both) in this case.

- Location: The study focused on seven regions in Tanzania (Dar es Salaam, Tanga, Arusha, Dodoma, Mwanza, Kigoma, and Mbeya), which represent seven major economic zones (Coastal, Eastern, Northern, Central, Lake, Western, and Southern) in Tanzania (Contractors Registration Board of Tanzania 2012). The selected regions are also business centres in the country as a result; many construction firms are located in these regions.

\section{Method}

\section{Sample design and sampling technique}

In investigating the impacts of entrepreneurial orientation (EO) dimensions on the profitability growth of local Tanzania's construction firms, a systematic sampling technique was used in this study to provide the actual sample size of the companies for a survey from each of the selected regions (i.e. Dar es Salaam, Mwanza, Mbeya, Arusha, Dodoma, Tanga, and Kigoma). Systematic sampling technique was opted because it is easier to implement it than other sampling techniques like simple random sampling (Elsayir 2014). Systematic sampling also "leads to a more representative survey than the simple random and hence it is preferred in implementation because of its ease and design efficiency" (Elsayir 2014; Opsomer et al. 2012). Although the firms involved in this study were selected from existing database of the Contractors Registration Board of Tanzania, the systematic sampling was considered appropriate to ensure that firms had an equal chance of being in the sampling frame.

A total of 338 representative contractors were selected from a population of 2854 local Tanzania's building and civil works firms available in the selected regions. The selection of 338 firms was guided by the sample size guidelines by Bartlett et al. (2001) and Krejcie and Morgan (1970). The list of the firms was taken from the database of the government-based Contractors Registration Board of Tanzania (Contractors Registration Board of Tanzania 2012). The construction firms selected were (a) commercially active in Tanzania from 2009 to 2012; (b) had valid contact details such as a mail address, a telephone number; and (c) located in the selected seven regions (i.e. Dar es Salaam, Tanga, Arusha, Dodoma, Mwanza, Kigoma, and Mbeya). The selected regions not only cover the majority of construction firms (53\% of all local construction firms registered in Tanzania at the end of 2012) but also represent differences in size in the Tanzania's construction industry (Contractors Registration Board of Tanzania 2012).

In obtaining the actual number of construction firms for a survey, the total number of construction firms available in each of the selected region was divided by the total number of the population sample (i.e. 2854 in this case) and multiplied by sample size required for a survey (i.e. 338). As a result of this computation, 202 construction firms were selected from Dar es Salaam region which had 1702 construction firms dealing with building and civil works. Thirty-nine firms were selected out of 331 firms available in Mwanza region, while 32 firms out of 274 firms were selected from Mbeya region. Out of 259 construction firms available in Arusha region, 31 firms were selected for a survey. In Dodoma region which had 145 construction firms, 17 firms were selected for a survey. As for Tanga region with 111 construction firms, 13 firms were selected for a 
survey. Finally, from Kigoma region, out of 32 construction firms available only 4 firms were selected for a survey. After obtaining the actual number of construction firms for a survey from each of the selected regions, a total of 338 construction firms surveyed was obtained by picking the first and each eighth firm appearing in the list of construction firms obtained from the database of the Contractors Registration Board of Tanzania.

\section{Data collection procedures}

Data reported in this study were collected through a structured questionnaire, which includes questions adopted from previous studies that also focused on EO and found significant results (Wong 2012; Yoon 2012; Schillo 2011; Gurbuz and Aykol 2009; Hornsby et al. 2002; Knight 1997), and then modified in order to meet the objectives of the study. The questionnaire was compiled in English and translated into Kiswahili (the national language of Tanzania). Thereafter, the top officials (in particular directors) of the identified 338 firms in the selected regions were contacted for interviews. One hundred ninety-seven questionnaires were collected with 65 questionnaires that were administered had incomplete information. Therefore, the statistical analysis was based on 132 questionnaires, reflecting a response rate of $39.05 \%$ of the targeted sample size. A response rate of $39.05 \%$ is acceptable for academic studies on the organizational level (Baruch and Holtom 2008).

\section{Measures}

\section{Entrepreneurial orientation (EO) measures}

Three EO dimensions (i.e. risk taking, innovativeness, and proactiveness) were assessed using 15 specific items. The items employed in this study were adapted from previous studies on entrepreneurial orientation (Wong 2012; Yoon 2012; Schillo 2011; Kreiser et al. 2002; Hornsby et al. 2002; Knight 1997; Lumpkin and Dess 1996). Respondents were instructed to rate the 15 items measuring EO dimensions on a 5-point Likert Scale with a scoring system ranging from $5=$ completely true, to $1=$ never true.

\section{Measuring a firm's profitability growth}

A number of indicators (factors) can be used to determine the profitability growth of a firm depending on what the researcher wants to achieve. However, the indicators which are often used by researchers are revenues, profits, market share, employees, and number of investment made by the firm (Lumpkin and Dess 1996; Hansen and Wernerfelt 1989). In this study, the profitability growth of companies was captured using "capital employed" and "annual profits" because they are the most common measures of profitability growth (Fairoz et al. 2010; Liao 2004; Delmar et al. 2003). Profitability growth was measured by the change in profitability from 2009 to 2012 with the information being provided by the respondents. A 3-year difference was selected because it was one of the time frames mostly used in the previous similar studies (e.g. Brush and Vanderwerf 1992; Cooper et al. 1991). Likewise, the link between EO dimensions and growth is stronger with a 3-year lag than with a 2-year lag or 1-year lag (Wiklund 1999; Zahra 1991). The actual values of profitability were obtained by computing the actual values of the profits generated and the capital 
invested by the individual firms using the formula that makes adjustments for differences in the size of firms (capitalization:

$$
\text { Profitability Change }=\frac{\text { Profit } 2012}{\text { Capital } 2012}-\frac{\text { Profit } 2009}{\text { Capital } 2009}
$$

With: Profit2012 = Total profit generated by the firm in the year 2012; Capital2012= Total value of capital invested by the firm in the year 2012; Profit2009=Total profit generated by the firm in the year 2009; and Capital2009=Total value of capital invested by the firm in the year 2009.

\section{Data analysis}

A multiple regression analysis was applied to test the impacts of individual dimension of entrepreneurial orientation (EO) on the growth of local Tanzania's construction firms. Regression analysis was used because "it is a statistical tool to investigate the relationships between variables, and it helps to estimate the quantitative effect of the causal variables upon the variable that they influence" (Sykes 1993). All analyses were conducted using the Stata 13 Statistical Package.

\section{Results}

\section{Descriptive analysis}

Table 1 demonstrates information on the firm's year of establishment, the owner's level of education, field of education, firm activities, firm employees in 2012, and firm locations.

Table 1 shows that many local Tanzania's construction firms (64.4\%) were established between the years 2001-2009 and only 6.1\% of firms were established before 1991 . The opening up of the economy for more entrepreneurial activity and an increase in the number of university graduates in engineering courses explains why most of the construction firms were established after the year 2000 (Muganda 2004). The illustration that most firm owners have bachelor degrees in engineering courses (i.e. 45.5\%) is an indication that educational background contributed to the establishment of construction firms in Tanzania. Further, the majority of the firms perform both building and civil activities (77.3\%). A few firms (9.1\%) concentrate solely on civil activities (such as the construction of roads, bridges, airports, and pipelines) and 13.6\% limit themselves to residential and commercial construction activities. Furthermore, Table 1 indicates that $35.6 \%$ of the firms across the sample surveyed had 0-10 employees in 2012. Firms with more than 50 employees accounted for $26.5 \%$ while only $6.8 \%$ of firms had between 41 and 50 employees. The possible reason behind the number of people employed in the construction firms is that most of the firms set on more workers when they have projects to execute. Finally, most of the respondents were located in Dar es Salaam Region, while only a few respondents were from Kigoma region because Dar es Salaam is the headquarters of most firms in Tanzania.

\section{Reliability test}

The reliability of the EO dimensions was assured by performing a factor analysis and measuring the factor validity, by employing correlation tests and calculating the Cronbach's alpha for each variable. Table 2 provides the results of principal factor analysis. 
Table 1 Firms' Characteristics and managers' profile

\begin{tabular}{|c|c|c|c|}
\hline & & Frequency & Percentage \\
\hline \multirow[t]{3}{*}{ Year of establishment } & Before 1991 & 8 & 6.1 \\
\hline & $1991-2000$ & 39 & 29.5 \\
\hline & $2001-2009$ & 85 & 64.4 \\
\hline \multirow[t]{8}{*}{ Level of education of firm owners } & Certificate in engineering courses & 21 & 15.9 \\
\hline & Certificate in other courses & 8 & 6.1 \\
\hline & Diploma in engineering courses & 7 & 5.3 \\
\hline & Diploma in other courses & 11 & 8.3 \\
\hline & Bachelor degree in engineering courses & 60 & 45.5 \\
\hline & Bachelor degree in other courses & 11 & 8.3 \\
\hline & Postgraduate in engineering courses & 10 & 7.6 \\
\hline & Postgraduate degree in other courses & 4 & 3 \\
\hline \multirow[t]{2}{*}{ Field of education } & Engineering courses & 98 & 74.2 \\
\hline & Other courses & 34 & 25.8 \\
\hline \multirow[t]{3}{*}{ Activities } & Building works & 18 & 13.6 \\
\hline & Civil works & 12 & 9.1 \\
\hline & Building and civil works & 102 & 77.3 \\
\hline \multirow[t]{6}{*}{ Employees in 2012} & 0-10 employees & 47 & 35.6 \\
\hline & 11-20 employees & 20 & 15.2 \\
\hline & 21-30 employees & 10 & 7.6 \\
\hline & 31-40 employees & 11 & 8.3 \\
\hline & 41-50 employees & 9 & 6.8 \\
\hline & 51 and above employees & 35 & 26.5 \\
\hline \multirow[t]{7}{*}{ Location } & Dar es Salaam & 71 & 53.8 \\
\hline & Tanga & 9 & 6.8 \\
\hline & Arusha & 22 & 16.7 \\
\hline & Dodoma & 2 & 1.5 \\
\hline & Mwanza & 18 & 13.6 \\
\hline & Kigoma & 4 & 3 \\
\hline & Mbeya & 6 & 4.5 \\
\hline
\end{tabular}

The results of the principal factor analysis (Table 2) confirmed the internal consistency of the measurements for the entrepreneurial orientation dimensions and suggested an elimination of three items (innovativeness4, proactiveness1, risk taking1) that were commanding the greater "uniqueness". According to Torres-Reyna (2012) and Bruin (2006a, $2006 \mathrm{~b}$ ), the greater the uniqueness of the variable, the lower the relevance of the variable to be considered in the factor model. These three specific items were not considered in the final analysis as they were not able to meet the thresholds recommended for both factor analysis and Cronbach's alpha. After dropping these three items, the final Cronbach's alpha levels measured were: innovativeness $(0.8839)$, proactiveness $(0.8491)$, and risk taking (0.8911). Therefore, all of the Cronbach's alpha values obtained are above "the recommended alpha level of 0.7" (Hair et al. 2007). Overall, the results indicate a high reliability of all EO dimensions measured.

Correlation analysis was used to measure correlations between the independent variables and the profitability growth of firms (dependent variable) as provided in Table 3. 


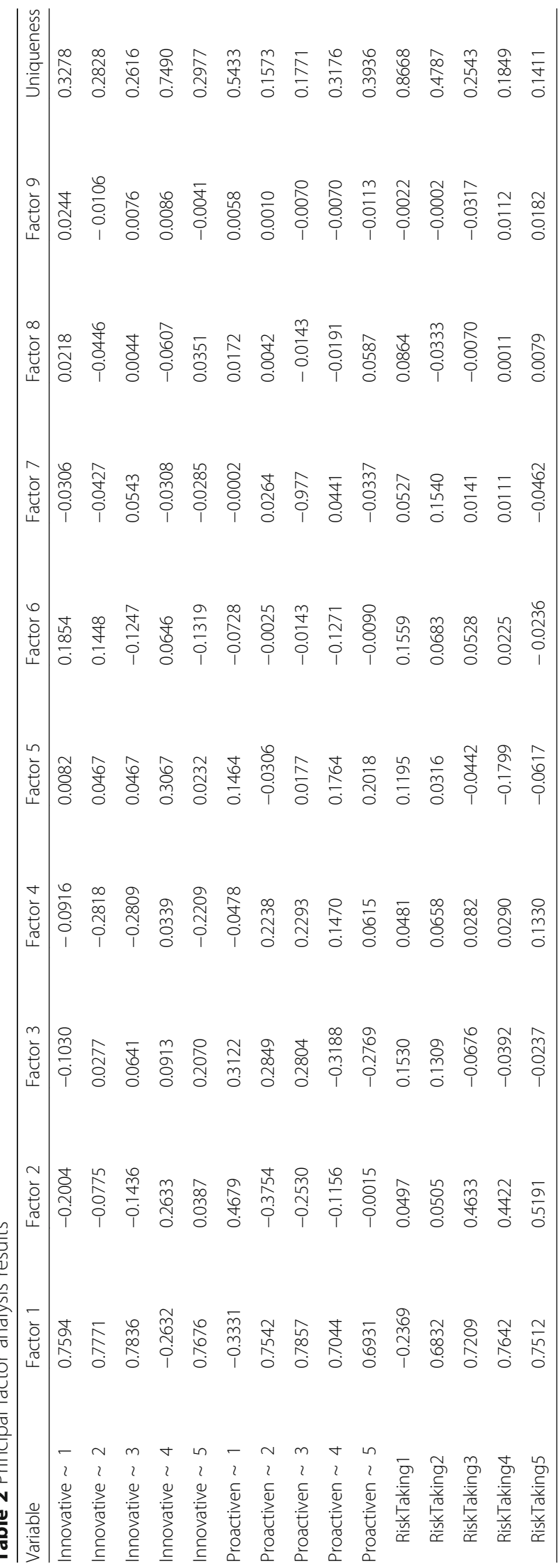


Table 3 Correlation analysis of variables

\begin{tabular}{llllll}
\hline & 1 & 2 & 3 & 4 & 5 \\
\hline 1. Profitability growth & 1 & & & & \\
2. Innovativeness & 0.2152 & 1 & & \\
3. Proactiveness & 0.0166 & 0.7838 & 1 & 1 & \\
4. Risk taking & 0.2598 & 0.6949 & 0.6807 & 0.3379 & 1 \\
5. Employees & 0.2896 & 0.1512 & 0.0699 & & \\
\hline
\end{tabular}

Table 3 shows that EO dimensions considered for this study (i.e., innovativeness, proactiveness and risk taking) are positively correlated with the profitability growth of the construction firms measured in this study. This indicates that the more the firm invests in innovativeness, proactiveness and risk taking, the more such a construction firm will experience a change in profits generated $(p<.05)$. The profitability growth of the construction firms recorded significant and positive correlation with innovativeness (coefficient 0.215 ) and proactivess (coefficient 0.0166 ). The profitability growth also recorded significant and positive correlation with risk taking (coefficient 0.2598 ). The positive and significant correlation has been exhibited also among the independent variables (innovativeness, proactiveness, and risk taking). At a $p$-value of 0.05 , a coefficient of 0.7838 has been recorded between innovativeness and proactiveness. A coefficient of 0.6949 has been recorded between innovativeness and risk taking. Finally, proactivess has recorded significant and positive correlation with risk taking (coefficient 0.6807 ). The fact that these correlations existed suggested that the dimensions of EO were interrelated. Thus, the correlation coefficients indicate an association between the variables (Mukaka 2012; Ratner 2009).

\section{Regression analysis}

A multiple regression analysis was performed to investigate the impacts of different EO dimensions on the profitability growth of local Tanzania's construction firms. Table 4 depicts the results regarding "the strength of the individual dimensions of EO" (Molokwu et al. 2013) and control variables against the growth of local Tanzania's construction firms. When testing the hypotheses, I first considered model 1 by regressing the control variables (location, firm activities, and number of employees) against the dependent variable (profitability change). The findings indicated no significant positive relationship between the control variables and the growth of local Tanzania's construction firms as the $p$-values for all control variables are greater than 0.05 at the $95 \%$ confidence interval (CI). This indicates that there is no link between the growth of local Tanzania's construction firms and the control variables involved in this study (number of employees, firm location, and firm activities). Model 2 focuses on the three EO dimensions, whereas, model 3 includes both the EO dimensions and the control variables. The firm location was compared to Dar es Salaam where most firms are located and building/civil engineering activities were modeled as a binary variable $(0=$ not active in this area, 1 =active in this area). Data sets with missing values were eliminated, leading to sample sizes of 101 (models 1 and 3) and 105 (model 2) respectively.

When the relationship between the EO dimensions and the profitability growth (Model 2) was tested, the findings indicated the regression model being statistically 
Table 4 Regression analysis for profitability growth

\begin{tabular}{|c|c|c|c|c|c|c|c|}
\hline \multirow[t]{2}{*}{ Variable } & \multirow[t]{2}{*}{ Pred. Sign. } & \multicolumn{2}{|c|}{ Model 1} & \multicolumn{2}{|l|}{ Model 2} & \multicolumn{2}{|c|}{ Model 3} \\
\hline & & Coeff. & $p$-value & Coeff. & $p$-value & Coeff. & $p$-value \\
\hline Innovativeness & $+(\mathrm{H} 1)$ & & & .3363 & $0.033^{* *}$ & .2989 & $0.068^{*}$ \\
\hline Proactiveness & $+(\mathrm{H} 2)$ & & & -.4902 & $0.004^{* * *}$ & -.4547 & $0.011^{* *}$ \\
\hline Risk taking & $+(\mathrm{H} 3)$ & & & .3270 & $0.016^{* *}$ & .2551 & $0.073^{*}$ \\
\hline Employees & & 0.0049 & $0.000^{* * *}$ & & & .0033 & $0.021^{* *}$ \\
\hline \multicolumn{8}{|l|}{ Location } \\
\hline 2 & & .1995 & 0.580 & & & .2425 & 0.491 \\
\hline 3 & & .3243 & 0.195 & & & .3086 & 0.203 \\
\hline 4 & & .3513 & 0.572 & & & -.0206 & 0.973 \\
\hline 5 & & .5019 & $0.059^{*}$ & & & .4156 & 0.112 \\
\hline 6 & & .5597 & 0.212 & & & .3915 & 0.376 \\
\hline 7 & & .6778 & $0.070^{*}$ & & & .6608 & $0.073^{*}$ \\
\hline \multicolumn{8}{|l|}{ Firm activities } \\
\hline Building & & -.1448 & 0.649 & & & -.0436 & 0.889 \\
\hline Civil & & -.3166 & 0.301 & & & -.2037 & 0.487 \\
\hline \multirow[t]{2}{*}{ Constant } & & -.1349 & 0.779 & -.1635 & $0.053^{*}$ & -.2306 & 0.623 \\
\hline & & \multicolumn{2}{|c|}{$\begin{array}{l}N=101, \text { Adj. } R^{2}=0.0744 \\
p<0.1\end{array}$} & \multicolumn{2}{|c|}{$\begin{array}{l}N=105, \text { Adj. } R^{2}=0.1171 \\
p<0.01\end{array}$} & \multicolumn{2}{|c|}{$\begin{array}{l}N=101, \text { Adj. } R^{2}=0.1405 \\
p<0.01\end{array}$} \\
\hline
\end{tabular}

${ }^{*} p<0.1,{ }^{* *} p<0.05,{ }^{* * *} p<0.01$

significant $(p<0.01)$ with an adjusted $R^{2}$ of 0.1171. A study by Ambad and Wahab (2013) also found the value of $R^{2}$ of about 0.11 when studied on entrepreneurial orientation among the firms in Malaysia. According to Newbold et al. (2010, p.464), models based on data collected from individual people as it was done in this study, the values of $R^{2}$ range between $0.10-0.20$ due to the dynamic change in human behavior. The results indicate that innovativeness and risk taking variables significantly increase profitability growth. These results support the hypotheses H1 and H3. Contrary to hypothesis 2 , the analysis shows that proactiveness significantly but negatively predicts the growth of productivity for local Tanzania's construction firms. This result thus, exhibits the rejection of hypothesis H2. In summary, the three dimensions of EO employed in this study are all good predictors for the profitability growth of local Tanzania's construction firms.

From the control variables used in model1and 3, the results reveal that only the number of employees is positive and significant $(p<.05)$. This indicates that there is a positive relationship between the number of employees (which is representing the firm size in this study) and the growth in profitability. This finding is consistent with findings by Pervan et al. (2017) that firm size influencing firm's profitability. Other control variables, such as location and firm activities were found to have no significant effects on the profitability growth of local Tanzania's construction firms.

\section{Discussion}

This study was carried out to investigate the impacts of different dimensions of entrepreneurial orientation (EO) i.e. innovativeness, proactiveness and risk taking on the profitability growth of local Tanzania's construction firms. The differences in the results of the EO dimensions justify the need to consider the impacts of individual dimensions 
of EO and not EO as a single variable. The results "are supported by the findings of other scholars who have claimed that the dimensions of EO have different impacts on the growth of firms" (Jalali et al. 2014; Rauch et al. 2009; Kreiser et al. 2002; Lumpkin and Dess 1996). With regard to hypotheses of this study, the discussion is mainly based on Model 2 and its results on the relationship between the EO dimensions and the growth of local Tanzania's construction firms. This is because Model 2 provides the relationship between EO dimensions and profitability growth of firms studied without influence of control variables.

The first result suggests that innovativeness has a positive and significant impact on the growth of local Tanzania's construction firms. The findings are consistent with other empirical findings that innovation can stimulate firm growth by pursuing new opportunities in the production process and markets (Fadda 2018; Wang and Yen 2012; Setiawan et al. 2012; Lim et al. 2010; Gambatese and Hallowell 2010; Slaughter 2010; Wiklund and Shepherd 2005; Klomp and van Leeuwen 2001). The findings of this study also comply with the findings of other scholars that "firms which invest in innovativeness and are also committed to introducing new products or services are likely to experience increased growth" (Kraus 2013; Zhang and Zhang 2012; Su et al. 2011; Li et al. 2009; Lee et al. 2001; Miller 1983). The positive effects of innovativeness on growth seem to work across different markets as they are similar in both developing and developed countries (Ambad and Wahab 2013; Wang and Yen 2012; Casillas and Moreno 2010; Klomp and van Leeuwen 2001). A study by Koe (2013) also demonstrated significant and positive effects of innovativeness on growth among the government-linked companies in Malaysia.

These findings on effect of innovativeness on growth profitability of the firms are also an indication that the innovativeness can take place in firms of different sizes (both large and small firms) across sectors. For example, while Gupta (2017), Wagner (2005), and Schumpter (1934) showed how large firms can take advantage of the capital they possess to engage in innovation that will influence their growth; the findings from Gupta (2017), and Audretsch and Acs (1991) also indicate that innovation can takes place in the small firms due to their flexibility and effective and informal internal communication. Mazzarol (2002) also indicated that "the ability of owners-managers and other factors that influence how employees relate in the firm determine the level of innovation in the firms as well as firm's growth".

The second result reveals that risk taking has a significant and positive impact on the profitability growth of local Tanzania's construction firms. These findings are consistent with the findings from other studies conducted across countries (Arshad et al. 2014; Ambad and Wahab 2013; Karacaoglu et al. 2013; Kraus 2013; Koe 2013; Zhang and Zhang 2012; Wang and Yen 2012; Su et al. 2011; Casillas and Moreno 2010; Li et al. 2009; Li et al. 2009; Wiklund and Shepherd 2005; Lee et al. 2001; Miller 1983). In those studies, "risk taking was also found to have positive effects on the growth of firms". Further, Wambugu et al. (2015) showed how "the ability of firms to stay competitive in the market is related to amount of risk taken". As indicated by Wang and Yuan (2011), risk "taking decisions are critical for the success of construction projects". Some of the risks that construction firms have to consider during the execution of projects include the variations in design, variations in construction programs, and changing customer demands (Zou et al. 2006). 
In general, the findings that both innovativeness and risk taking variables measuring positive and significant effect on firm growth has a support of many previous studies across different countries and sectors. For example, Gupta (2017), Kumarfeli and Semasinghe (2015), and Filser and Eggers (2014) have found that "both innovativeness and risk taking are positively and significantly associated with growth of firms". Maldonado-Grizman et al. (2017) also measured signicant and positive effects on Mexican firms.

The third result shows that proactiveness has a significant effect, although it is negatively associated with the growth of local Tanzania's construction firms. The findings are consistent with a few studies (e.g. Ambad and Wahab 2013; Kraus 2013) which also found that proactiveness is negatively related with business growth. Other empirical findings that found a negative relationship between proactiveness and firm's growth include Kumarfeli and Semasinghe (2015), and Filser and Eggers (2014). However, these findings on proactiveness are not consistent with the findings from the majority of previous studies, which were conducted across countries. Most of the findings from those studies demonstrated a positive and significant association between proactiveness variable and growth of businesses or firms (Fadda 2018; Arshad et al. 2014; Karacaoglu et al. 2013, Wang and Yen 2012; Kraus et al. 2012; Zhang and Zhang 2012; Su et al. 2011; Casillas and Moreno 2010; Li et al. 2009; Li et al. 2009; Wiklund and Shepherd 2005; Lumpkin and Dess 2001; Klomp and van Leeuwen 2001; Lee et al. 2001; Miller (1983). Nazri et al. (2015) and Anlesinya et al. (2015) were also other studies exhibited significant and positive effects on performance of firms in developing countries.

\section{Conclusion}

This study analyzed the impacts of different EO dimensions - innovativeness, proactiveness, and risk taking on the growth of local Tanzania's construction firms. Innovativeness and risk taking measured positive and significant association with profitability growth of the local Tanzania's construction firms, whereas proactiveness measured significant but negatively associated with profitability growth of the same firms. With regard to the findings of proactiveness variable, which show a negative relationship with profitability growth of the local Tanzania's firms; it is an indication that the construction market environment of Tanzania does not enable future demand to be forecasted. Moreover, a weak institutional framework and a lack of sustainable relationship between the Tanzania's construction firms with other key stakeholders in the industry such as clients and suppliers can also prevent such firms from realizing the advantages of being proactive. This is an indication that local Tanzania's construction firms are not able "to adopt a bold, aggressive posture in order to maximize the probability of utilizing potential opportunities" (Debrah and Ofori 2005) available in the construction industry of Tanzania.

\section{Research implications}

Managers in the construction sector of Tanzaniashould develop policies that promote innovativeness and risk taking among employees in managing their firms. The findings of the study revealed that individual EO dimensions have different impacts on the growth of firms. This can be explained by how a firm becomes innovative by placing 
emphasis on the development of new and improved services, production processes, resource organization methods, market developments and adjusting organizational strategy to the changing business environment which translates into a firm's enhanced growth.

Furthermore, risk taking has a positive and significant impact on the growth of local Tanzania's construction firms. This proves that by not being too risk averse in trying and deploying new ways of doing business, making strategic decisions, and exploiting new opportunities can have significant impact on firm's growth. However, managers are advised only to take calculated risks (Naldiet al. 2007) in their efforts to achieve growth strategies for firms (Mintzberg 1973). With regard to proactiveness, high emphasis on forward-thinking management practices can harm profitability which indicates insufficient market efficiency in the construction sector of Tanzania.

In general, the results of this study clearly demonstrate that impacts of EO dimensions on the growth of firms vary. This indicates how the use of the aggregated EO may provide inaccurate results in some research contexts. Hence, these findings add important information in clarifying the effects of individual dimensions of EO on growth of firms. Furthermore, the findings of this study clearly exhibit how EO dimensions studied can be applied in overcoming challenges related to growth of firms. It is therefore, in such situations owner-managers of the firms can really benefit by creating an environment that favor a firm to be proactive, innovative, and able to take risks in pursuing emerging opportunities in the market that that differentiate and give an advantage edge to their firm from competitors (rivals). This study further advances entrepreneur's knowledge about the effects of EO dimensions on the growth of firms, particularly in the construction sector considering that EO research has received less attention in the Tanzania's construction sector.

\section{Limitations and future research}

This study focused on local construction firms of Tanzania only. Thus, future studies could focus on both local and foreign construction firms operating in Tanzania. This approach could further highlight the effects of EO dimensions on the growth of (foreign) construction firms operating in Tanzania. This study also has some limitations in terms of external validity due to data being only collected from owners and top officials of local Tanzania's construction firms. Future empirical would therefore solicit information from both owners and employees of construction firms. The inclusion of employees in a similar study would expose a different view from the employers' view which this study focused on. It would also be meaningful to conduct a longitudinal study to observe impacts of EO on the growth of local Tanzania's construction firms over time. Such kind of analysis can provide additional insights on the importance of the EO dimensions through the growth cycle of an organization or when different economic conditions change. Since the study is also limited to Tanzania's context, another interesting study would be to conduct a comparative study on the growth of similar construction firms in different countries. This approach could be used to test if the effects of EO dimensions perform similarly in different cultures and markets. 


\section{Acknowledgements}

The author wish to thank the editor-in-chief and the external language editor for their helpful contribution. Many thanks to the anonymous reviewers for insightful comments and suggestions. I also appreciate the contributions made by Prof. Dr. Peter Letmathe of RWTH Aachen University, Germany in improving the contents of this paper. Again, I thank the respondents for responding to the questionnaire, I distributed to them.

Funding

The University of Dar es Salaam, Tanzania supports this research by providing fund to cover data collection process.

\section{Availability of data and materials}

Data analyzed for this study were collected by the author from the construction firms in Tanzania. The data supporting the results reported in this manuscript can be obtained from the author in excel form.

\section{Authors' contributions}

The author collected the data, performed the statistical analysis, and drafted and approved the final manuscript.

\section{Competing interests}

The author declares he has no competing interests.

\section{Publisher's Note}

Springer Nature remains neutral with regard to jurisdictional claims in published maps and institutional affiliations.

Received: 10 October 2018 Accepted: 17 December 2018

Published online: 17 January 2019

\section{References}

Abrams, R. (2004). What Business Should I Start? Seven Steps to Discovering the Ideal Business You. Palo Alto: The Planning Shop.

Alarape, A. A. (2013). Entrepreneurial orientation and the growth performance of small and medium enterprises in Southwestern Nigeria. Journal of Small Business \& Entrepreneurship, 26(6), 553-577.

Ambad, S. N. A., \& Wahab, K. A. (2013). Entrepreneurial orientation among large firms in Malaysia: contingent effects of hostile environments. International Journal of Business and Social Science, 4(16), 96-107.

Anlesinya, A., Eshun, P., \& Bonuedi, A. A. (2015). Entrepreneurial dimensions and profitability nexus: evidence from micro enterprises in the retail sector in a developing country. Journal of Small Business and Entrepreneurship Research, 3(7), 79-87.

Antoncic, B., \& Zorn, O. (2004). The mediating role of corporate entrepreneurship in the organizational support-performance relationship: an empirical examination. Managing Global Transitions, 2(1), 5-14.

Arshad, A. S., Rasli, A., Arshad, A. A., \& Zain, Z. M. (2014). The impact of entrepreneurial orientation on business performance: a study of technology-based SMEs in Malaysia. Procedia-Social and Behavioral Sciences, 130, 46-53.

Audretsch, D. B., \& Acs, Z. J. (1991). Innovation and size at the firm level. Southern Economic Journal, 57(3), 739-744.

Awang, A. B., Ahmad, Z. A., \& Subari, K. A. (2010). Entrepreneurial orientation among Bumiputera small and medium agrobased enterprises (Bsmaes) in West Malaysia: policy implication in Malaysia. International Journal of Business and Management, 5(5), 130.

Bartlett, J., Kotrlik, J., \& Higgins, C. (2001). Organizational research: appropriate sample size in survey research. Information Technology, Learning, and Performance Journal, 19(1), 43-50.

Baruch, Y., \& Holtom, B. C. (2008). Survey response rate levels and trends in organizational research. Human Relations, 61(8), 1139-1160.

Bhardwarj, B. R., Shushil, \& Momaya, K. (2011). Drivers and enablers of corporate entrepreneurship: case of a software giant from India. Journal of Management Development, 30(2), 187-205.

Bossink, B. A. G. (2004). Managing drivers of innovation in construction networks. Journal of Construction Engineering and Management, 130(3), 1-34.

Brettel, M., Chomik, C., \& Flatten, T. C. (2015). How organizational culture influences innovativeness, Proactiveness, and risktaking: Fostering entrepreneurial orientation in SMEs. Journal of Small Business Management, 53(4), 868-885.

Bruin, B. J. (2006a). Newtest: command to compute new test. UCLA: Statistical Consulting Group https://stats.idre.ucla.edu.

Bruin, J. (2006b). New test: command to compute new test. UCLA: Statistical Consulting Group https://stats.idre.ucla.edu.

Brush, C., Bruin, A., Gatewood, E., \& Henry, C. (2006). Women entrepreneurs and the global environment for growth: a research perspective. Cheltenham: Edward Elgar, U.K.

Brush, C. G., \& Vanderwerf, P. A. (1992). A comparison of methods and resources for obtaining estimates of new venture performance. Journal of Business Venturing, 7(2), 157-170.

Cader, H. A., \& Norman, D. W. (2006). Entrepreneurship education for the African informal sector. In A. Fayolle \& H. Klandt (Eds.), International entrepreneurship education (pp. 277-296). Cheltenham: Edward Elgar Publishing.

Casillas, J. C., \& Moreno, A. M. (2010). The relationship between entrepreneurial orientation and growth: the moderating role of family involvement. Entrepreneurship and Regional Development, 22(3-4), 265-291.

Contractors Registration Board of Tanzania. (2012). Professional / Technical Reference. https://www.crbtz.org/contractorsclass. asp. Accessed 13 Oct 2012.

Cooper, A.C., Gimeno-Gascon, F.G., \& Woo, C.Y. (1991). A resource-based prediction of new venture survival and growth. In Academy of management proceedings, $1991(1), 68-72$

Covin, J. G., \& Slevin, D. P. (1989). Strategic management of small firms in hostile and benign environments. Strategic Management Journal, 10(1), 75-87.

Covin, J. G., \& Slevin, D. P. (1991). A conceptual model of entrepreneurship as firm behaviour. Entrepreneurship Theory and Practice, 16(1), 7-25. 
Davidsson, P., Achtenhagen, L., \& Naldi, L. (2005). Research on Small Firm Growth: A Review. In European Institute of Small Business. https://eprints.qut.au/2072.

Dean, T. J., \& McMullen, J. S. (2007). Toward a theory of sustainable entrepreneurship: reducing environmental degradation through entrepreneurial action. Journal of Business Venturing, 22(1), 50-76.

Debrah, Y. A., \& Ofori, G. (2005). Emerging managerial competencies of professionals in the Tanzanian construction industry. International Journal of Human Resource Management, 16(8), 1399-1414.

Delmar, F., Davidsson, P., \& Gartner, W. B. (2003). Arriving at the high-growth firm. Journal of Business Venturing, 18(2), 189-216.

Elsayir, H. A. (2014). Comparison of precision of systematic sampling with some other probability samplings. American Journal of Theoretical and Applied Statistics, 3(4), 111-116.

Erken, H, Donselaar, P., \& Thurik, R. (2008). Total factor productivity and the role of entrepreneurship. JENA economic research papers,

Fadda, N. (2018). The effects of entrepreneurial orientation dimensions on performance in the tourism sector. New England Journal of Entrepreneurship, 21(1), 22-44.

Fairoz, F. M., Hirobumi, T., \& Tanaka, Y. (2010). Entrepreneurial orientation and business performance of small and medium scale enterprises of Hambantota district Srilanka. Asian Social Science, 6(3), 34-46.

Farja, Y., Gimmon, E., \& Greenberg, Z. (2016). The effect of entrepreneurial orientation on SMEs growth and export in Israeli peripheral regions. New England Journal of Entrepreneurship, 19(2), 24-40.

Ferreira, J., \& Azevedo, S. G. (2008). Entrepreneurial orientation (EO) and growth of firms: key lessons for managers and business professionals. Problems and Perspectives in Management, 6(1), 82-88.

Filser, M., \& Eggers, F. (2014). Entrepreneurial orientation and firm performance: a comparative study of Austria, Leichtenstein and Switzerland. South Africa Journal of Business Management, 45(1), 55-65.

Gambatese, J. A., \& Hallowell, M. (2010). Enabling and measuring innovation in the construction industry. Construction Management and Economics, 29(6), 553-567.

Gibb, J., \& Haar, J. M. (2010). Risk taking, innovativeness, and competitive rivalry: a three-way interaction towards firm performance. International Journal of Innovation Management, 14(5), 871-891.

Gupta, R. (2016). Entrepreneurship and firm growth: review of literature on firm-level entrepreneurship and small firm growth. South Asian Survey, 22(1), 1-14.

Gupta, V. K., \& Batra, S. (2016). Entrepreneurial orientation and firm performance in Indian SMEs: universal and contingency perspectives. International Small Business Journal: Researching Entrepreneurship, 34(5), 660-682.

Gurbuz, G., \& Aykol, S. (2009). Entrepreneurial management, entrepreneurial orientation and Turkish small firm growth. Management Research News, 32(4), 321-336.

Hair, J. F., Money, A., Samouel, P., \& Page, M. (2007). Research methods for business. West Sussex: Wiley.

Hansen, G. S., \& Wernerfelt, B. (1989). Determinants of firm performance: the relative importance of economic and organizational factors. Strategic Management Journal, 10(5), 399-411.

Hayton, J. C., \& Kelley, D. J. (2006). Competency-based framework for promoting corporate entrepreneurship. Human Resource Management, 45(3), 407-427.

Hornsby, J. H., Kuratko, D. F., \& Zahra, S. A. (2002). Middle manager's perception of the internal environment for corporate entrepreneurship: assessing a measurement scale. Journal of Business Venturing, 17, 253-273.

Hughes, M., \& Morgan, R. E. (2007). Deconstructing the relationship between entrepreneurial orientation and business performance at the embryonic stage of firm growth. Industrial Marketing Management, 36, 651-661.

Hult, G. M. M., Hurley, R. F., \& Knight, G. A. (2004). Innovativeness: its ancedents and impact on business performance. Industrial Marketing Management, 33, 429-438.

Jalali, A., Jaafar, M., \& Ramayah, T. (2014). Entrepreneurial orientation and performance: the interaction effect of customer capital. World Journal of Entrepreneurship, Management and Sustainable Development, 10(1), 48-68.

Karacaoglu, K., Bayrakdaglu, A., \& San, F. B. (2013). The Impact of Corporate Entrepreneurship on Firm's Financial Performance: Evidence from Istanbul Stock Exchange Firms. International Business Research, 6(1), 163-175.

Kasumawardhani, A., McCarthy, G., \& Perera, N. (2009). Framework of Entrepreneurial Orientation and Networking: A Study of SMEs Performance in a Developing Country. In Proceedings of the Australian and New Zealand Academy of Management Conference (pp. 1-16). Adelaide: Australian and New Zealand Academy of Management.

Ketchen, D., \& Short, J. (2012). Strategic Management: Evaluation and Execution (v.1.0). Chapter 2, 70-75, https://my.uopeople. edu/pluginfile.php/57436/mod_book/chapter/122442/BUS\%205117\%20strategic-management-evaluation.pdf. Accessed 7 Apr 2013.

Kim, H., Hur, D., \& Schoenherr, T. (2015). When buyer-driven knowledge transfer activities really work: a motivationopportunity-ability perspective. Journal of Supply Chain Management, 51(3), 33-60.

Klomp, L., \& Van Leeuwen, G. (2001). Linking innovation and firm performance: a new approach. International Journal of the Economics of Business, 8(3), 343-364.

Knight, G. (1997). Cross-cultural reliability and validity of a scale to measure firm entrepreneurial orientation. Journal of Business Venturing, 12, 213-225.

Koe, W. (2013). Entrepreneurial orientation and entrepreneurial orientation (EO) and companies. Journal of Enterpreneurship, Management and Innovation, 2, 21-41.

Kraus, S. (2013). The role of entrepreneurial orientation in service firms: empirical evidence from Austria. The Service Industries Journal, 33(5), 427-444.

Kraus, S., Rigtering, J. P. C., Hughes, M., \& Hosman, V. (2012). Entrepreneurial orientation and the business performance of SMEs: a quantitative study from the Netherlands. Review of Managerial Science, 6(2), 161-182.

Krauss, S., Frese, M., Friedrich, C., \& Unger, J. M. (2005). Entrepreneurial orientation: a psychological model of success among Southern African small business owners. European Journal of Work and Organizational Psychology, 14(3), 315-344.

Kreiser, P. M., Marino, L. D., \& Weaver, K. M. (2002). Assessing the psychometric properties of the entrepreneurial orientation scale: a multi-country analysis. Entrepreneurship Theory and Practice, 26(4), 71-94.

Krejcie, R. V., \& Morgan, W. (1970). Determining Sample Size for Research Activities. Educational and Psychological Measurement, 30, 607-610.

Krueger, N. F. (2005). Sustainable entrepreneurship: broadening the definition of opportunity. In Conference proceedings in 19th National Conference of United States Association for Small Business and Entrepreneurship (USASBE) (pp. 13-16). 
Kumarfeli, K. I., \& Semasinghe, D. M. (2015). The Impact of Entrepreneurial Orientation on the Growth of SMEs in Srilanka. International Conference on Business, Marketing and Information System Management (BMISM'15) November 25-26, 2015 (France).

Lee, C., Lee, K., \& Pennings, J. M. (2001). Internal capabilities, external networks, and performance: a study on technologybased ventures. Strategic Management Journal, 22(6-7), 615-640.

Lee, S. M., \& Lim, S. (2009). Entrepreneurial orientation and the performance of service business. Service Business, 3(1), 1-13.

Li, Y. H., Huang, J. W., \& Tsai, M. T. (2009). Entrepreneurial orientation and firm performance: the role of knowledge creation process. Industrial Marketing Management, 38(4), 440-449.

Liao, J. (2004). Entrepreneurial growth: predictors and indicators. New York: Routledge.

Lim, J. N., Schultmann, F., \& Ofori, G. (2010). Tailoring competitive advantages derived from innovation to the needs of construction firms. Journal of Construction Engineering and Management, 136(5), 568-580.

Lumpkin, G. T., \& Dess, G. G. (1996). Clarifying the entrepreneurial orientation construct and linking it to performance. The Academy of Management Review, 21(1), 135-172.

Lumpkin, G. T., \& Dess, G. G. (2001). Linking two dimensions of entrepreneurial orientation to firm performance: the moderating role of environment and industry life cycle. Journal of Business Venturing, 16(5), 429-451.

Mahemba, C. M., \& Bruijn, E. J. D. (2003). Innovation activities by small and medium-sized manufacturing enterprises in Tanzania. Creativity and Innovation Management, 12(3), 162-173.

Mahmood, R., \& Hanafi, N. (2013). Entrepreneurial orientation and business performance of women-owned small and medium enterprises in Malaysia: Competitive advantage as a mediator. International Journal of Business and Social Science, 4(1), 82-90.

Maldonado-Grizman, G., Martinez-Serna, M., \& Pinzon-Castro, S. Y. (2017). Entrepreneurial orientation and growth in Mexican small business. Business Journal of Management and Sustainability, 7(1), 94-105.

Maliyamkono, T. L., \& Bagachwa, M. S. D. (1990). The second economy in Tanzania. London: James Curey.

Mazzarol, T. W. (2002). Innovativeness in small firms: an exploratory study of the perspectives of growth oriented ownermanagers. International Journal of Innovation Management, Policy \& Practice, 4(1-3), 30-40.

Miles, M. P., \& Arnold, D. R. (1991). The relationship between marketing orientation and entrepreneurial orientation. Entrepreneurship Theory and Practice, 15(4), 49-65.

Miles, M. P., Arnold, D. R., \& Thompson, D. L. (1993). The interrelationship between environmental hostility and entrepreneurial orientation. Journal of Applied Business Research, 9(4), 12-24.

Miller, D. (1983). The correlates of entrepreneurship in three types of firms. Management Science, 29(7), 770-791.

Minniti, M., \& Levesque, M. (2008). Recent developments in the economics of entrepreneurship. Journal of Business Venturing, 23, 603-612.

Mintzberg, H. (1973). Strategy making in three modes. California Management Review, 16(2), 44-53.

Molokwu, V. B., Barreria, J., \& Urban, B. (2013). Entrepreneurial orientaion and corporate governance structures at the firm level in South Africa. SA Journal of Human Resources Management, 11(1). https://doi.org/10.4102/sajhrm. v11i1.443.

Morgan, R.E., \& Strong, C. A. (2003). Business performance and dimensions of strategic orientation. Journal of Business Research, 56,163-176.

Muganda, A. (2004). Tanzania's economic reforms - and lessons learned. In Case Study for the World Bank Shanghai Conference on Scaling Up Poverty Reduction, Shanghai.

Mukaka, M. M. (2012). A guide appropriate use of coefficient in medical research. Malawi Medical Journal, 24(3), 69-71.

Naldi, L., Nordqvist, M., Sjöberg, K., \& Wiklund, J. (2007). Entrepreneurial Orientation, Risk Taking, and Performance in Family Firms. Family Business Review, 20(1), 33-47.

Naman, J. L., \& Slevin, D. P. (1993). Entrepreneurship and the concept of fit: a model and empirical tests. Strategic Management Journal, 14, 137-153.

National Bureau of Statistics (2013). The economic survey of Tanzania. The Ministry of Finance, Dar es Salaam, Tanzania. National Bureau of Statistics. (2013). The Economic Survey of Tanzania. Dar es Salaam.

Nazri, M. A., Wahab, K. A., \& Omar, N. A. (2015). The effect of entrepreneurial dimensions on Takaful agency's business performance in Malaysia. Jurnal Pengurusan, 45, 83-94.

Ndunguru, P. C. (2006). Entrepreneurial Motives and Culture: A Case Study of Southeast and Southern Highland of Tanzania. Unpublished Ph.D. Thesis, University of Dar es Salaam.

Neneh, B. N., \& Van Zyl, J. (2017). Entrepreneurial orientation and its impact on firm growth amongst SMEs in South Africa. Problems and Perspectives in Management, 15(3), 166-178.

Newbold, P., Carlson, W., \& Thorne, B. (2010). Statistics for business and economics. $7^{\text {th }}$ Edition, New Jersey Pearson Education, Prentince Hall, USA.

North, D., \& Smallbone, D. (2000). The innovativeness and growth of rural SMEs during the 1990s. Regional Studies, $34(2), 145-157$.

Olomi, D. R. (2009). African Entrepreneurship and Small Business Development: Context and Process. Dar es Salaam: Otme Company Limited.

Onuha, G. (2007). Entrepreneurship. AlST International Journal, 10, $20-32$.

Opsomer, J. D., Francisco-Fernández, M., \& Li, X. (2012). Model-based non-parametric variance estimation for systematic sampling. Scandinavian Journal of Statistics, 39, 528-542.

Peng, X. (2015). Risk Taking and Firm Growth. RIETI Discussion Paper Series 15-E-061.

Pervan, M., Pervan, I., \& Curak, M. (2017). The influence of age on firm performance: evidence from the Croatian food industry. Journal of Eastern Europe Research in Business and Economics, 2017, 618681. https://doi.org/10.5171/2017.618681.

Philemon, J. R., \& Kessy, S. S. (2009). Top management characteristics and firms' performance in Tanzania: a case of selected firms. Business Management Review, 18(2), 1-31.

Pratono, A. H., Wee, T. C., Syahchari, D. H., \& Nugraha, A. T. (2013). The direct effects of EO and innovation on firm performance. American Journal of Economics, 3(1), 1-6.

Ratner, B. (2009). The correlation coefficient: its values range between $+1 /-1$, or do they? Journal of Targeting, Measurement and Analysis of Marketing, 17(2), 139-142. 
Rauch, A., Wiklund, J., Lumpkin, G. T., \& Frese, M. (2009). Entrepreneurial orientation and business performance: commulative empirical evidence. Entrepreneurship Theory and Practice, 33(3), 761-788.

Rauch, A., Wiklund, J., Lumpkin, G. T., \& Frese, M. (2009). Entrepreneurial orientation and business performance: an assessment of past research and suggestions for the future. Entrepreneurship Theory and Practice, 33(3), 761-787.

Reijonen, H., Tammi, T., \& Saastamoinen, J. (2014). SMEs and public sector procurement: does entrepreneurial orientation make a difference? International Small Business Journal. https://doi.org/10.1177/0266242614556661.

Rugumamu, S. (1997). Entrepreneurship Development: Some Reflections from Tanzania. In Rutashobya L. K. and Olomi D. R. 1999. African Entrepreneurship and Small Business Development, DUP, Dar es Salaam.

Rweyemamu, J. (1979). The historical and institutional setting of Tanzania industry. In K. Kim (Ed.), Papers on the political economy of Tanzania. London: Heinemann.

Santarelli, E., \& Vivarelli, M. (2007). Entrepreneurship and the process of firms' entry, survival and growth. Industrial and Corporate Change, 16(3), 455-488.

Sarker, S., \& Palit, M. (2015). Strategic orientation and performance of small and medium enterprises in Bangladesh. International Journal of Entrepreneurship and Small Business, 24(4), 572-586.

Schillo, S. (2011). Entrepreneurship orientation and company performance: can the academic literatures guide managers? Technology Innovation Management Review, 1(2), 20-25.

Schumpter, J. (1934). The theory of economic development. Harvard University Press, Cambridge MA.

Schumpeter, J. A. (1965). Economic Theory and Entrepreneurial History. In H. G. Aitken (Ed.), Exploitations in Enterprise. Boston: Harvard University Press.

Setiawan, H., Erdogan, B., \& Ogunlana, O. (2012). Corporate entrepreneurship for contracting companies: the current issues. In Proceedings 28th Annual ARCOM Conference (pp. 3-5).

Shane, S., \& Venkataraman, S. (2000). The promise of entrepreneurship as a field of research. The Academy of Management Review, 25(1), 217-226.

Sykes, A. O. (1993). An introduction to regression analysis. Chicago working paper in law and economics. University of Chicago, The Law School.

Slaughter, E. S. (2010). Implementation of construction innovations. Building Research and Information, 28(1), 2-17.

Soriano, D. R. (2010). Management factors affecting the performance of technology firms. Journal of Business Research, 63(5), 463-470.

Stevenson, H. H., \& Jarillo-Mossi, J. C. (1986). Preserving entrepreneurship as companies grow. The Journal of Business Strategy, $7(1), 10-23$.

Su, Z., Xie, E., \& Li, Y. (2011). Entrepreneurial orientation and firm performance in new ventures and established firms. Journal of Small Business Management, 49(4), 558-577.

Sutton, J., \& Olomi, D. R. (2012). An Enterprise map of Tanzania. London: International Growth Centre.

Swierczek, F. W., \& Ha, T. T. (2003a). Motivation, entrepreneurship and the performance of SMEs in Vietnam. Journal of Enterprising Culture, 11(1), 47-68.

Swierczek, F. W., \& Ha, T. T. (2003b). Entrepreneurial orientation, uncertainty avoidance and firm performance: an analysis of Thai and Vietnamese SMEs. The International Journal of Entrepreneurship and Innovation, 4(1), 46-58.

Temu, S. S. (1997). Sources of Financing Small Scale Enterprises in Tanzania (Unpublished PhD. Dissertation). Germany: University of Bremen.

Torres-Reyna, O. (2012). Getting started in factor analysis (using Stata 10). Princeton University, USA.

Varukolu, V., \& Park-Poaps, H. (2009). Technology adoption by apparel manufacturers in Tirupur town, India. Journal of Fashion Marketing and Management, 13(2), 201-214.

Vij, S., \& Bedi, H. S. (2012). Relationship between entrepreneurial orientation and business performance: a review of literature. The IUP Journal of Business Strategy, 9(3), 17-31.

Wagner, E. R. (2005). Innovation in large versus small companies: insights from the US wood products industry. Management Decision, 43(6), 837-850.

Wambugu, A. W., Gichira, R., Wanjau, K. N., \& Mung'atu, J. (2015). The relationship between risk taking and performance of small and medium agro processing enterprises in Kenya. International Journal of Economics, Commerce and Management, III(12), 441-455.

Wang, C. L. (2008). Entrepreneurial orientation, learning orientation, and firm performance. Entrepreneurship Theory and Practice, 32(4), 635-656.

Wang, C. L., \& Altinay, L. (2012). Social embeddedness, entrepreneurial orientation and firm growth in ethnic minority small businesses in the UK. International Small Business Journal, 30, 3-23.

Wang, H., \& Yen, Y. (2012). An empirical exploration of CEO and performance in Taiwanese SMEs: a perspective of multidimensional construct. Total Quality Management and Business Excellence, 23(9), 1035-1044.

Wang, J., \& Yuan, H. (2011). Factors affecting contractor's risk attitudes in construction projects: case study from China. International Journal of Project Management, 29(2), 209-219.

Weinzimmer, L. G., Nystrom, P. C., \& Freeman, S. J. (1998). Measuring organizational growth: issues, consequences, and guidelines. Journal of Management, 24(2), 235-262.

Wennekers, R. T. (2004). Entrepreneurship, small business, and economic growth. Journal of Small Business and Enterprise Development, 11(1), 140-149.

Wiklund, J. (1999). The sustainaibility of the entrepreneurial orientation-performance relationship. Entrepreneurship theory and practice, 24(1), 37-48.

Wiklund, J., \& Shepherd, D. (2005). Entrepreneurial orientation and small business performance: a configurational approach. Journal of Business Venturing, 20, 71-91.

Wong, S. K. S. (2012). The influences of entrepreneurial orientation on product advantage and new product success. Journal of Chinese Entrepreneurship, 4(3), 243-262.

Ying-hong, Z. (2007). Firm's Propensity to Risk Taking in Entrepreneurial Strategy Making: An Empirical Study Based on China's Transitional Economy. 2007 International Conference on Management Science and Engineering.

Yoon, H. (2012). The performance effects of entrepreneurial orientation: evidence from South Korean start-ups. International Journal of Arts and Commerce, 1(4), 248-254. 
Zahra, S. A. (1991). Predictors and financial outcomes of corporate entrepreneurship: an exploratory study. Journal of Business Venturing, 6(4), 259-285.

Zahra, S. A. (1993). New product introduction in established companies: associations with industry and strategy variables. Entrepreneurship Theory and Practice, 18(2), 47-70.

Zahra, S. A. (1996). Governance, ownership, and corporate entrepreneurship: the moderating impact of industry technological opportunities. Academy of Management Journal, 39(6), 1713-1735.

Zahra, S. A., \& Garvis, D. M. (2000). International corporate entrepreneurship and firm performance: the moderating effect of international environmental hostility. Journal of Business Venturing, 15, 469-492.

Zain, M., \& Hassan, A. E. (2007). The impact of corporate entrepreneurship on company growth in a hostile environment. In $7^{\text {th }}$ Global Conference on Business and Economics.

Zhang, Y., \& Zhang, X. (2012). The effect of entrepreneurial orientation on business performance a role of network capabilities in China. Journal of Chinese Entrepreneurship, 4(2), 132-142.

Zou, P. X., Zhang, G., \& Wang, J. Y. (2006). Identifying key risks in construction projects: life cycle and stakeholder perspectives. International Journal of Construction Management, 9(1), 1-14.

Zulkifli, R. M., \& Rosli, M. M. (2013). Entrepreneurial orientation and business success of Malay entrepreneurs: religiosity as moderator. International Journal of Humanities and Social Science, 3(10), 264-275.

Submit your manuscript to a SpringerOpen ${ }^{\circ}$ journal and benefit from:

- Convenient online submission

- Rigorous peer review

- Open access: articles freely available online

High visibility within the field

- Retaining the copyright to your article

Submit your next manuscript at $\boldsymbol{\nabla}$ springeropen.com 